\title{
The Personality of a University Teacher from the Perspective of Academic Culture
}

\author{
Sirotová, Mariana ${ }^{a}$; Frýdková, Eva ${ }^{b}$ \\ ${ }^{a}$ Department of Pedagogy ,University of St. Cyril and Methodius in Trnava, Philosophical \\ Faculty, Slovak Republic, ${ }^{b}$ Department of Pedagogy, University of St. Cyril and Methodius \\ in Trnava, Philosophical Faculty, Slovak Republic
}

\begin{abstract}
This submission deals with the personality of a university teacher as a member of an academic environment and a bearer of academic culture. The work also includes the results of a quantitative survey executed via questionnaire presenting the FF UCM (Philosophical Faculty of St. Cyril and Methodius University in Trnava) students' views of university teachers and their perception of the teachers in the educational process of the university. The analysis of the opinions confirms that students not only perceive the personal qualities of a teacher, but also evaluate his/her educational activity.
\end{abstract}

Keywords: academic culture; academic atmosphere; university teacher; university student; survey of students'opinions and attitudes. 
University education develops and changes in the same way as the society itself. Therefore, the role and position of a university teacher from the perspective of his/her educational activity, scientific research as well as his/her overall influence of the students' personality also changes. The preference of materialism in the life style of people and a lack of respect for the principles of humanism and democracy in society, that bring changes into human behavior, reflect themselves in the university academic culture as well. University teachers should, therefore, be the bearers of positive academic behavior, which is manifested in all of their activities, but in connection with the development of students' personalities mainly in their educational activity. How did the educational activity of a university teacher change compared to the past? The question is not difficult, but despite this we find out by analyzing the literature, that the fundamentals of educational activity haven't changed. What has changed is the environment in which it takes place.

Z. Kolář and co. (2012) describe a university teacher as an expert in a particular scientific discipline, who has a mandate to lead the teaching of university students in his/her field of expertise and at the same time fulfills tasks in the area of science, introduces and defends the results of his/her research work, that leads to preparation of scientific and educational texts. According to D. Linhartová (In. Slavík and co., 2012) the term university teacher encompasses his/her pedagogical activity. The author puts the teacher into a role of an expert who takes part in the students's socialization, in boosting students' responsibility for their education and in the position of a manager she sees him/her as a facilitator of students' education. She also emphasizes the teacher's duty to analyze his/her own activity and its educational impact. It is obvious that educational activity occupies a priority position in the work of a university teacher, through which he/she develops the personality of university students. Therefore, it requires an adequate attention.

When taking into account general psychological findings, that social behavior is also a function of the behavior of others, it is necessary to pay attention to the teacher-student relationship, which is often characterized by dominance. The teacher acts as a guide and leads a student's educational activity and, therefore, he/she is often declared, but also perceived by students, as the superior. In the interest of developing students' personality and improving the quality of the educational process it is necessary to change this incorrect identification into a partner-like relationship, which is mutually enriching. J. Vašutová (1999) states, that a teacher-student relationship should be collegial with just a slight level of superiority. This level might be expressed as a teacher's natural authority. "A teacher should be the bearer of the culture of relationships he/she requires from his/her students, he/she should be a person of principle, but at the same time tolerant, have high expectations of the students as well of his/her own pedagogical performance in the educational process and last but not least a teacher should be friendly and respectful of a student's personality. 
The attitudes and relationships of a university teacher are reflected into the attitudes of the students toward the teacher himself" (Sirotová, 2012, p. 127).

In general, culture is defined as a set of habits, relationships, institutions, arts and other features characterizing a society or a social group. The term itself derives from a Latin word cultura, which means "to cultivate" (Gažová, 2009). Culture is part of social relationships in a society, relationships and behavior of individuals in a certain social group and it is necessary to cultivate it continually. Each social group is characterized by a certain culture of relationships, which derive from a historical nature of its origin and are modified by the society itself. Materialism, focus on consumption, lack of respect towards humans, which are endemic in society today, all spread into the university environment as well and become reflected in academic culture. Academic culture is formed by the academic atmosphere in the university environment. V. Šucha (2010, p. 69) considers academic atmosphere an abstract category, that cannot be defined, it can't be written down, but either we feel it or we don't. He compares is to human love, which cannot be clearly defined, but a person feels it, when he loses it. "Academic atmosphere in the life of a university is needed in the same way as love is needed in the life of a human". Although the author states that academic atmosphere cannot be described, he offers its "building blocks", which are:

- Public discussions, which are the tools of an idea, of its defense, but also a public test of its acceptability and value. Public discussions should be neither personal nor offensive to other participants despite the fact that they are open and often critical. Criticism shouldn't be considered a personal attack as well as a personal attack shouldn't be hidden behind an expert critique. Open, meaningful public discussions help create a positive academic atmosphere.

- Public lectures are activities offering room not only for university teachers and students, but also for scientists and experts from the field as well as the public. An appropriate combination of subjects, careful preparation, promotion and realization of public lectures can help enrich the academic atmosphere of a university in the expert area.

- Openness towards art and culture as a tool of social communication and as a space for social contact and penetration. Organization of art related events could enliven the academic stereotypes and open "the windows into another world", which is seemingly fundamentally different from the world of education.

- The ethical dimension. V. Šucha (2010, p. 72) emphasizes its importance with the idea: "without ethics and morality a university would be just a shiny apple that is rotten to the core". He recommends, that every university prepares its own ethical codex and sets up ethical commissions, which would deal with prevention and judgement of contentious cases 
of codex violations. A university should find a way to include morality and ethics into the basic principles of its existence.

The personality of a member of an academic environment dominates in all of the above stated "building blocks". The members of an academic environment are university teachers, university students, scientific workers and other experts. And, as stated above, the academic culture is formed mainly by the relationships and behavior of the members of an academic environment. University teachers should be the bearers of academic culture, should create a positive academic atmosphere and thus influence the development of students' personalities as well as the overall development of a university environment and its positive view in society. It is, therefore, necessary to focus on the issues of university teachers' personality and of its perception by university students.

The theoretical background is followed by a survey focusing on the satisfaction of FF UCM students with various aspects of their study. The survey took place in the year 2017 with the help of a questionnaire created by a commission of quality control at FF UCM and its aim was to find out how satisfied the students were with their choice of school, the process and organization of their study, with accommodation and board, free time, but also with the study subjects, the realization of the teaching and the teachers. In regards to the subject of this work, we only present the results pertaining to university teachers.

So far (at the time of preparation of this article the survey hadn't been concluded) 193 students of bachelor and master study programs from all years of study and study programs at the FF UCM took part in the survey. The collected student opinions are stated in total sums for the entire sample of survey subjects with selected quotations of verbal comments.

A university teacher is evaluated by students based on basic qualities characterizing his/her personality. It means his/her education, skills, personality traits and character.

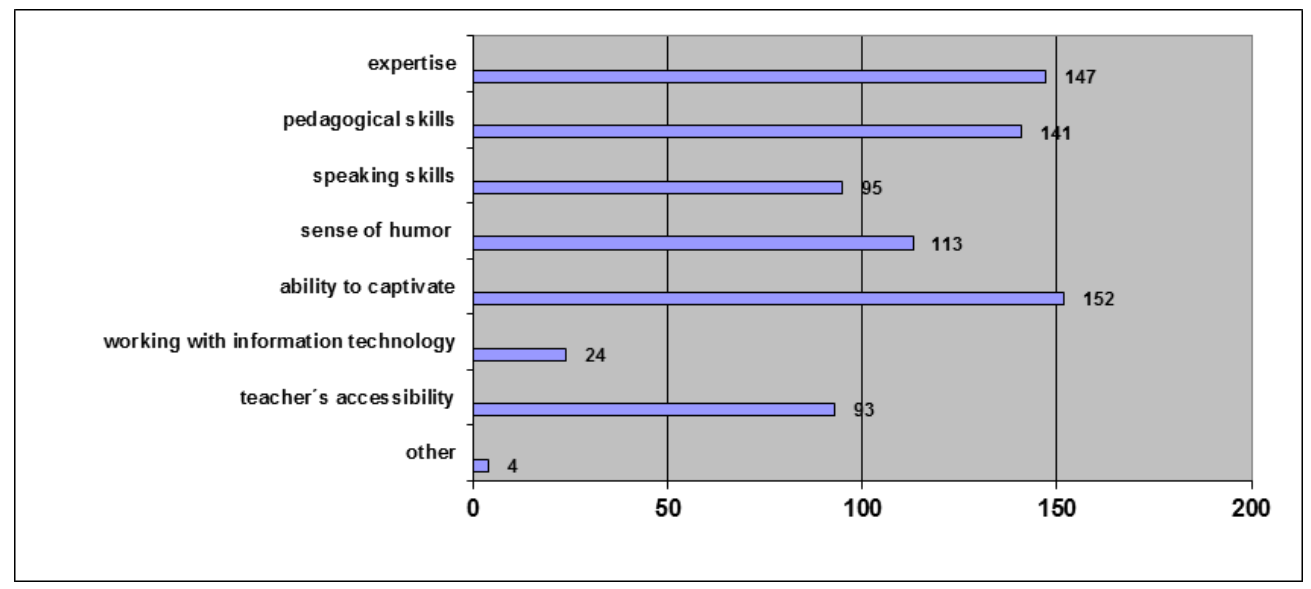


The "other" category related mainly to the personality traits of a teacher and his/her character. It, however, also included assessments closely related to the previous criteria. A university teacher is positively assessed when he/she possesses these traits (in order from the most commonly occurring to the less often occurring ones):

- Humane approach and amiability - it means the love of students expressed in the quality of pedagogical work, in an attempt to get to know them as much as possible and to consider them equal partners. ( ... "Humanity, respect of students. I'm presenting a case of a real professor of our faculty. Deep respect." "Humane approach, amiability, immense willingness to help and a perfect knowledge of his field...", ..."Humanity, but there are some, who lack this quality"...).

- Willingness - an attempt to accommodate the students or to help is one of the most valued qualities among students. It depends, however, how this willingness is interpreted, as it may involve a wide range of possibilities. (..."every time, there is problem, either a technical one or we don't know something, or anything, we know we can write to him and he always sorts it out." ,... "She is always willing to give advice even if a student approaches her with a problem not directly connected to her competencies or to the competencies of the department").

- Pleasant conduct and appearance - are often important factors influencing students' activity and motivation to work. (... "overall appearance and impression are also very important, ..."it is apparent that he really enjoys the subject he teaches and this enthusiasm transfers onto students", ... "stylishly dressed" ...).

- An ability to motivate and captivate - according to students a teacher is good, when he/she is able to captivate via his/her knowledge, organization of his/her work, his/her qualities, but also if he/she is able to motivate. (..."some repeat themselves quite often, they are boring, unable to captivate students"..., ..."his preparation for lessons - a teacher should know what he wants to teach the students and his teaching shouldn't be chaotic" ..., ..."character traits are fine, ability to engage, enliven the lessons, humanity").

There had also been a few negative phenomena and teachers' qualities emerging from the students's statements. Teachers should try to eliminate these in their work. 


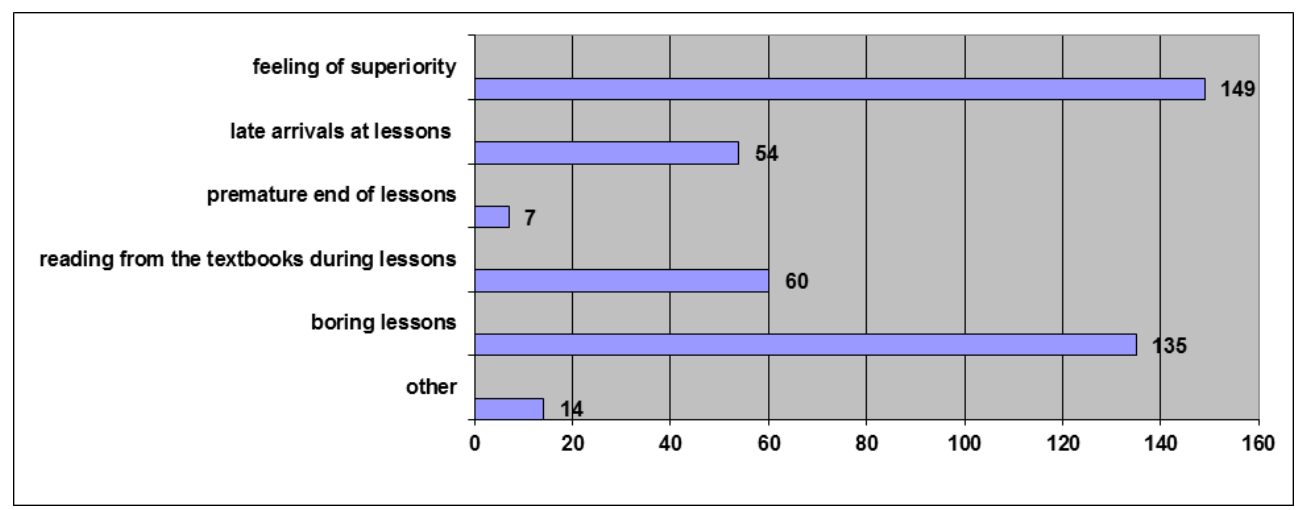

The "other" category included mainly the phenomena already listed in the graph. However, the most common had been the following:

- $\quad$ Irresponsibility - students negatively view teachers who are not thorough in their work, in preparation for their pedagogical activity or in their realization and those who arrive late for their lessons. (... "not prepared for lessons, boring, prolonging the lessons at the expense of students" free time (sometimes even the whole break)", ... "unpunctuality, repeating the same thing over and over (and then being late with the curriculum)").

- Teacher's arrogance, inadequate conduct - students often stated their experience with teachers' arrogance and mockery of students. (... "the way he expresses himself at lessons is shown through elements of haughtiness and ridicule of students"..., ... "arrogant, superior approach to students, he makes us feel it at almost every lesson, ... "self-conceited, he acts in a condescending way toward some students, he belittles them in front of the group,...”.)

- $\quad$ Bias, preferring some students over others - university teachers often don't realize the consequences of their biased behavior towards some students or obvious preference of some students over others. (... "non-transparency and a change of rules during the semester", ... "Superficiality, subjective approach to students based on sympathies, unfairness").

- Inadequate presentation skills - a university teacher should possess adequate verbalization skill and according to students' statements should be able to present his knowledge not only verbally, but also via technical tools, which are currently considered desirable and necessary. (..."awfully long slides, which we have to transcribe and at the same time take notes of what he talks about - impossible to do two things at once", Datavideo projectors, which are in all the class-rooms, are used by less than half of the teachers.") 
Teachers that behave arrogantly and are unable to captivate students through their expert knowledge or through linguistic or technical tools are not viewed as experts by students It is, therefore, natural that these negative qualities stated by students cannot lead to a positive influence of students or to the improvement of educational process quality and a teacher's own work.

Based on the students' statements from the questionnaire, we can assert that university teachers are subjected to much demand relating not only to the time needed for preparation for lessons, but also to the qualities of their character, their knowledge and the ability to captivate. This demand undoubtedly influences students' perception of a teacher, but also their overall attitude towards individual study subjects and university study itself. Both the positive and the negative qualities the students mentioned were based on their own experience. According to students a teacher should, first of all, be able to captivate, be an expert in his/her field of study with adequate pedagogical skills, but at the same time also be humane, have a good sense of humor and be willing to help. These qualities seem to have a significant influence on students' attitude toward their university study.

\section{References}

Gažová, V. (2009). Acta Culturologica - Úvod do kulturológie (zväzok 17). Bratislava: FF UK.

Koláŕ, Z. \& kol. (2012). Výkladový slovník z pedagogiky. Praha: Grada.

Sirotová, M. (2012). Rola vysokoškolského učitel’a v procese habituálnej edukácie a jej vplyv na hodnotovú orientáciu študentov. In: Pedagogica actualis III. Trnava: UCM. 125-141.

Slavík, M. \& kol. (2012). Vysokoškolská pedagogika. Praha: Grada.

Šucha, V. (2010). Aby univerzita mala dušu. Bratislava: VEDA.

Vašútová, J. (1999). Vybrané otázky vysokoškolské pedagogiky. Praha: UK.

Zákon o vysokých školách 131/2002 Z. z. slovenská republika 